\title{
Patient-oriented Care-History, Progress and Current State according to Literature and in Practice in the Czech Republic
}

\author{
Marcela Waldsbergerová ${ }^{1}$ and Treslova Marie ${ }^{2}$ \\ 1. Medical Ward, Brothers of Charity Hospital in Brno, Czech Republic \\ 2. South Bohemia University in Ceske Budejovice, Faculty of Health and Social Studies, Ceske Budejovice 37005, Czech Republic
}

\begin{abstract}
This work is focused on "patient-oriented care", which belongs to modern style of health care including nursing. Such health care emphasises holistic approach with focus on communication, partnership, ethic aspects of human interactions and which supports active collaboration between the patient and also his/her family and the nursing staff. In Czech scientific literature the term "patient-oriented care" is rarely encountered. Single given definition found for this topic was present in legal norm bulletin The Concept of Czech Nursing [1] which was however defined as care focused on patient problems not on care connected treatments. International literature had therefore to be addressed. Question remains whether patient-oriented care is even possible in practice when it is basically omitted from Czech scientific literature. The aim of this research was to define the term "patient-oriented care" based on historical point of view, its characteristics and sources from Czech and international literature and try and apply such care in new nursing methods of approach. This research was conducted on theoretical level. Method of analysing review documents and analytically comparative approach were applied. The total 83 scientific publications were analysed with 55 reviews, 22 articles and 6 virtual sources. The area of interest was defined to include forms of application of patient-oriented care in nursing history, the characteristics of patient-oriented care in Czech and international literature, necessary conditions for successful use of patient-oriented care and novel methods of approaching patient-oriented care. We found that contrary to the Czech Republic US has established patient-oriented care as one of the pivotal research subjects onto which much interest is focused and which is frequently being published. There is an established project in Austria focused on implementation of the concept of patient-oriented care into public health care. In the Czech Republic this term is only mentioned in the legislative decree, together with the method of nursing process but not used in practice. Due to absence or broader application of patient-oriented care approach in the Czech Republic and in order to make this approach more effective, further education on this approach has been introduced in the form of life-long education. The way the newly acquired knowledge is implemented in practice must be the subject of further research. The trend of the new approach toward the patient-oriented care should inspire further focus on education and care provision including nursing. The necessity for a change is felt particularly in the current intense argument on the insufficient numbers of general nurses and the levels of their qualification education in this country. Better agreement should be reached regarding evaluation of patient-oriented care to ensure it really is conducted in order to benefit the patient.
\end{abstract}

Key words: Patient-oriented care, holism, communication, education, ethical principles.

\section{Introduction}

Generally speaking the approach toward a patient can be view both from the position of the patient and the health care provider. The latter sees as optimal care that corresponds to the current level of science and technology. However, seen from the patient point of

Corresponding author: Treslova Marie, Ph.D., research fields: communication, elderly population and didactics in nursing. view optimal care relates to satisfying his needs and to sympathetic behaviour and approach from the health care providers. Given care depends not only on the concept of the particular field, but also on moral approach toward everybody in need of care according to his needs and values [2,3]. Chosen approach toward the patient is a current problem that is discussed and taught on theoretical level but nursing personell are often at a loss how to proceed in practice [4]. In Czech 
literature the term patient-oriented care is rarely encountered. Its definition is found in The Concept of Czech nursing [1] as care focused on patient problems not on treatment connected to the care. This is the only concrete definition found in Czech scientific literature found. Foreign literature [5-7] defines this term and its use in practice is clearer giving information about what is necessary for patient-oriented care and how to include it into the care system as a whole. One of the first authors using this term and realising the importance to focus more on the patient/client was the humanitarian psychologist Carl Rogers in the 1950s. Initially this type of therapy was termed "non-directive" consulting but was due to criticism from several experts renamed to patient-oriented approach. Patient self-concept was important for Rogers. He saw the patient in the centre of the therapeutic interest focusing on what the patient/client sees as important and he/she views him/herself and the situation [8]. Rogers starts from the thesis that the client knows best. "It is the client that knows what hurts him and where the pain is, and that in the end finds the way forward" [9]. The precondition is that two people are in contact with each other, here as the nurse and the patient. Patient-oriented approach emphasises authenticity, ability to listen and capability to appreciate in the sense of encouragement and human development which requires certain skills, change of approach and last but not least experience $[10,11]$. From the patient side the important contribution is his/her collaboration and will to get healthy. Rogers as well as [12] point out the necessity to master basic skills the nurse should use to strengthen patient potential regarding his/her vulnerability [10]. Authors emphasising this care regard relationship during treatment as important and further see the need to improve mutual exchange of information, response to emotions, helping the patient to cope with insecurities, support his/her capability to take decisions and maintain self-management. Several organisations have made steps towards such care. Nevertheless, sufficient awareness about what this care means, how it should be provided and why it is important is still not clarified. Some sources describe this care differently from the truth, for instance as focused on the illness, the technology or the care takers. The management of IOM-(Institute of Medicine) defines this care as one that honours patient preferences and values while trying to see to his/her problems in a complex way [13]. Technical innovations in themselves cannot guarantee reaching this aim if the relationship between the patient and the care takers and communication about subjects worrying the patient are not improved. Nykl [10] builds on Roger's theory and brings many new initiatives about what this type of care should involve. It is above all quality personal, professional and organisational relationships helping patients to become active participants of their care by getting encouraged and motivated toward such approach. The role of nursing personnel is thus transferred from central towards a position aimed at partnership, solidarity, empathy and cooperation. As holistic approach toward patients stems from this humanitarian philosophy, we have tried to find ways to use patient-oriented care in the Czech Republic, with the focus on the psycho-social area of this approach.

\section{Methodology}

The main aim of this research was to define the term "patient-oriented care". These research questions were posed: 1. Which form did patient-oriented care have in the history of nursing care? 2. How is patient-oriented care characterised in Czech and international literature? 3. What prerequisites are necessary regarding the provision of patient-oriented care? 4. What is the position of new approach methods in patient-oriented care? Research was conducted on theoretical level using document analysis using systematic review (gradual data construction) and analytical cooperation work [14]. The subjects of investigation were primary and secondary documents, primarily articles by American authors that clearly focus on the given topics. Key words patient-oriented care, relationship 
patient-nurse, dignity, autonomy were used. These key words were searched in Czech, Slovak, English and German languages. The total of 83 scientific publications were used, 55 monographies, 22 articles and 6 virtual sources. Text analysis was conducted with focus on four areas: forms of realisation of patient-oriented care in the history of nursing, characteristics of patient-oriented care in Czech and international literature, necessary prerequisites for fulfilled patient-oriented care and new approach methods regarding patient-oriented care.

\section{Results and Discussion}

\subsection{Characteristics of Term Patient-oriented Care in National and International Literature}

In US the question of patient-oriented care is the central pillar in health care research to which much attention is turned and which is frequently published. The reason seems to lay in the fact that the founder of this approach is C. R. Rogers who was a known American psychiatrist and professor. Holistic approach also started with American nurses in the 1960s. Their aim was to maintain balance between satisfying human needs and growing technical progress that aims the work of nurses towards following physiological functions of the patient rather than his/her needs. This aim is clear from nursing conception models of theory of nursing $[15,16]$. American association of holistic nurses AHNA [17] says in their rules of professional approach: "Inseparable part of nursing should be respect for life, dignity and equal rights. Nursing care is given in context that honours the holistic essence of humans, understands the body, soul and spirit" [18].

Also in Austria there exists a specified project with the aim to incorporate the concept of patient-oriented care into public health care system. The Austrian model of patient-oriented care (PIK-Patientinnenorientierte integrierte Krankenbetreuung) has not been initiated solely by the health care providers as a reflection on insufficiencies in such concept of care. Instead its introduction was enabled by support from Vienna municipal and health insurance companies. Alpen-Adria University of Klagenfurt is also involved with continuous evaluation. Austrian health care was concerned with steps to improve approach and coordination of nursing staff to better correspond to the main standpoint with focus on the patient. Reserves and resources for possible potential were sought that would ensure systematic changes leading to more effective care. Therefore the process was focused on the overall organization of the caring process. The main project of PIK is increasing quality of all dimensions of the treatment process in order to ensure patient satisfaction. Among the important factors belong, among others, education of patient and family members or information on availability of medical aids. The subject of monitoring of this project is better definition and evaluation of health care quality, evaluation of availability of services and their flexibility as well their reaction on patient needs. Further aim is ensured continuity of care, which means a better coordination of work at hospitals, outpatient units, mobile hospices and connected social sphere. We believe that the case of current Austrian state government and health care is a very suitable model for thought and inspiration.

In the Czech Republic this care is defined in the Concept of Czech health care which outlines the methodology for nursing as nursing process specifically oriented on the patient as "patient centred care" in contrary to "task oriented care" [1]. In other words it defines "Holistic nursing as the prerequisite for ensuring complex individualised nursing care with the treated individual is in the centre of attention as a whole bio-social-spiritual being placed in certain environment and state of health" [19]. Holisms as well as the nursing process represent the basis for theoretical teaching of nursing. Unfortunately the situation in practice makes it impossible to apply this approach as a standard disregarding the given legal norm. We therefore doubt that patient-oriented care is applicable in reality. 
3.2 Patient-oriented Care in Nursing History in the Czech Republic

We followed historical connections to see which forms of nursing were used in patient-oriented care in the past periods of time. We found that this care has never been complexly applied. In publications by [20-23] there is a clear evolution of the nursing profession leading towards the current highly professional care. All major social events were also seen to influence into the patient care. With the progress of technology and science the society turned to specialisation and organisational changes in nursing. Up to the 1950 the standard model of care comprised of family doctors and nurses visiting patients in their homes. The broader family could thus be observed over long periods of time, where the way of life, social standard, family anamnesis, economic conditions and other circumstances. Both analysis of symptoms and the given care on individual level could therefore be given [24]. When looking back at this concept of care especially the great individual effort to reach optimal results should be appreciated. Long term cooperation and life-long relationship brings trust without which quality care of a patient is quite impossible. Haškovcová [24] also means that limited technical background and possibility to diagnosis that could not meet the current status left the doctors to lean on mental findings analysed by philosophical theses. The doctor represented not only professional but also reliable authority for the patient and his/her family. In the period of socialism the process of nursing development was disrupted which is important to take into account for comprehending the current state of the nursing situation in the Czech Republic. Patient approach turned paternalistic due to social and ideological causes. This was practically the only way to give and receive care and these cultural and socioeconomic changes are still reflected on the current ideal of complex care [25]. The pitfall in the needed process of change lies in the remaining standpoints of the care takers - the authority that prefers their own knowledge and experience in spite of the different standpoints of the patients. The paternalism is thus repeated as the patient is relieved of own responsibility and personal activity to influence or change own care which leads to passive acceptance and blind trust of the experts. Haškovcová [24] believes that a transfer of personal responsibility onto the expert or institution the patient is rid of a part of own worries and happily seduces to the opinions and decisions of the more skilled. Clearly in case of emergency or in case both sides comply paternalistic approach is acceptable. On the other hand when the patient is incapable, unable or unwilling of communicating his/her needs it is an obligation of the care takers to ensure psychoeducational intervention and cooperate with the family [26]. In case of patient refusal of active cooperation the process of patient-oriented care loses its essential part and with it its complexity [10]. Tóthová [27] also points out that the treatment decisions are currently moving towards patient and care giver equivalency and active cooperation from the patient.

\subsection{Patient-oriented Car in Literature}

The above mentioned facts engage us to focus on patient-oriented care in Czech and international literature. From the 1990s we have had the possibility to study the American approach to health care which has been diametrically different from ours by its basic philosophic concept of holism. The patient is seen as a client paying for his/her care and has economically clearly formulated right to influence its quality. Health care is clearly not exploited; on the other hand, it is not generally available to all. Liberal health care policy on which American medical system is based, gives the patients/clients large share of independence regarding the choice of medical care and treatment approach. Health care staff is financially dependent and treatments given are the expression of market competition [28]. Despite all the economic aspects the primary point of health care remains the above 
mentioned approach of the psychologist Rogers whose main point is patient centred care with emphasis on self-concept perception [9]. The prerequisite for deepened relationship is approaching the patient without prejudice through suitable communication aimed at partnership between the client and the health care providers; know how to appreciate. At the same time, the vulnerability of the patient/client must be perceived together with respect for his/her autonomy [6]. Great potential lies in the communication skills whether during description of symptoms, pains or negative feeling or during encouragement dialog. Health care personnel can in this way help the patient to discover his/her own inner sources of motivation [7, 12]. However, in the Czech Republic the communication with the patient and his/her family is continuously neglected which is also why the development and changes in the area of nursing in the US represent an inspiration. Andrysek [29] states that the differences between given care in the Czech Republic and abroad lies not in expertise. Similarly Nyk1 [10] or Šiffelová [11] see the differences in personal opinions, communication and perception of patient personality. They point out the reality that individual approach to patients is precisely what Czech health care providers needed to revaluate when working abroad.

The research shows that the opinions of Czech and foreign expects are more or less identical. Comparison of sources was conducted regarding the limitations of the concept itself, how it was historically developing and implemented into practice and education of qualified experts. The patient-oriented approach is basically agreed on and its benefits are generally recognised as positive and important by all authors. They are based on the humanitarian and psychological theory of C. R. Rogers - approach focused on the individual [10]. Where there were differences, these were sooner problems regarding the implementation of patient-oriented care not the concept per se, not the value of partnership and active patient approach based on equality of both sides. Differences in individual countries are found only in the views on the implementation of such care, not on the philosophical aspect, methods and theories.

\subsection{Prerequisites for Application of Patient-oriented Care in the Czech Republic}

Clearly, the available literature or theoretical aspects of nursing represent the basis for patient-oriented care and offer solid ground comparable to international standards. Their implementation is however questionable. Health care reforms brought after year 1990 meant many changes both in education and nursing practice leading to patient advantage. Changes also focused on the perception of a patient as a human being and strengthening nurse autonomy. One of the prerequisites for patient-oriented care is the educational level of nursing. Vaňková [30] pointed out certain weaknesses that also influence practical education-regarding supervision of specialised work training. Insufficiencies are seen particularly in connection between theoretical and practical parts of the education where the ethical and social aspects of nursing are neglected. As a consequence mentoring has been included into the practical parts of education. Patient-oriented care should also be supported by greater interest from the management regarding the staff, particularly certified nurses, regarding educational programs, mentoring and supervisions which should be implemented into the practical concept in the adaptation process of every nurse in a new working place. Supervisions in nursing have so far not been implemented on general basis into company culture in the Czech Republic [31].

Another prerequisite for patient-oriented care is individualised care. Currently patient-oriented care is conducted through the method of the nursing process given by The Concept of nursing [27, 32] argues that his method is the most suitable when the holistic approach and continuity of care are considered. Despite this care is still not implemented or vied positively in 
many health care facilities. Particularly the extended documentation necessary is very cumbersome for the nursing staff to handle. Frühaufová [33] has in her work concentrated on the comparison between nurses working with the nursing process method that had conducted their studies prior to the concept of university studies for nurse qualification were established in 2004. She says that the problems lie in difficulties to adopt the new procedures as compared to nurses who had conducted studies after the new concept had been established. The largest systematic problem that can influence the patient-oriented care is undoubtedly the current over-use of health care. This reality is caused by the health care system in the Czech Republic being based on solidarity and equity [28]. Growing bureaucracy brings stress and feeling of over-work together with emotional and physical overload which leads to continuous fatigue and physical burnout. Bártlová [43] states that in this state of things the care taker cannot be against his/her best effort be capable of individual, personal care focused on all elements of the human being as is emphasised in the holistic approach. Haškovcová [24] sees one of the causes in medicalisation of problems that used to be frequent in our health system and system supported in the past years. The trust for the medical institutions prevails to this day even in cases that could be easily treated in home environment and when alternative treatments could be chosen. The current system of home care enables interventions of time-limited treatments covered by the health insurance but not the follow-ups required by the patients and their families. Many patients therefore choose institution care though they perceive it as the necessary evil. A possible alternative is better interconnection between medical and social networks in order to ensure that the home care gets appreciated. In such case the care takers and the patients pose the question as to who is the determining factor in the patient-oriented care scenario. Is it the insurance companies and their limits or bad coordination between the health care system and other sectors? Holčík [35] means that the transformation of the health care sector has not brought the expected changes and it is therefore necessary to create a health care system that would motivate and appreciate the cooperation between patients, their families and all health care organisations.

\subsection{New Methods of Approach}

New approach methods-concepts, significantly improve the quality of patient-oriented care. Abroad concept strategies are a matter of course and furthermore a strictly formulated basic condition for care giving. Furthermore, individual medical facilities get financed only when patient-oriented care is practiced there. At the same time, the employer is responsible for education of the nursing personnel enabling each at least four courses a year on the approach method of preference. On the other hand, in national settings using these methods is not at all common instead they belong to individual initiatives. Generally speaking conceptual strategies based on qualified, specialised and life-long education are in many cases ignored. Where individual approach from nurses is lacking the hospital should follow up on the quality of the given care and ensure the necessary knowledge and skills through seminars. In improving health care a large potential seems to lie in methods that support not only the healing process but that also have therapeutic effect. According to Filatová [36] such methods represent both cognitive and behavioural aspect of care that can greatly influence the quality of patient lives. As Raiter [37] says assessing patient satisfaction with the given care is meaningful only when medical facilities dispose of good comparative quality indicators. Such health care indicators must be defined in a way that enables the quality to be reliably monitored. Hudon [6] states that for patient-oriented care the first step is to identify the dimensions of the given care and clearly define the concept limits. In clinical practice the most frequent assessment methods determining the experience of the nursing staff when 
meeting patients are their self-evaluation and satisfaction. Concepts and models stemming from psychological findings on the patient have therefore slowly but surely started to be used in some medical establishments even in our setting. These are primarily geriatric and palliative care establishments where traditional methods were not efficient or where aimed patient-oriented care was not in practice. The patients were fed, washed and medicated but were they satisfied? Was anybody interested in their life story? Did anybody think about their values and preferences in their lives? It was clearly shown that without mental support physical state of the patients cannot be satisfied regardless any medication used. This one-sided patient view was in need of a chance. Among the most frequently used methods belong basal stimulation, validation, sense activation, kinaesthetic mobilisation and psychobiographic model of care established by prof. Erwin Böhm [38-42]. The given conceptual methods emphasise the inseparability of a human being, nursing staff and environment. They stem from mutual interactions, verbal and non-verbal communication and are realised by activated senses, interactions through movement and touch. This means a reactivation of mental ability using all human skills. To understand the inside world of the patient necessitates working with patient and his biography. Beside the change in personal approach the given methods also require passing accredited educational courses. These methods pose no further requirements on nursing practice; they can be implemented into normal, everyday tasks, such as patient communication, positioning or mobilisation. Effectivity of introduction of the individual concepts into nursing care has been proven by plentiful empirical research abroad. Positive influence was found both in the increased life quality of the patients and improved team work of the care takers which can be seen as a unifying factor [35].

\section{Conclusions}

Seen through history of civilisation patient-oriented care has never been fully complex. From the beginnings of primitive societies when the strongest force behind the care for patient, wounded or otherwise incapacitated members was preservation of the family line and its physical cooperation during securing food and protection. These were probably not deeds of care and comfort which eventually came during the following period. Christianity introduced the important aspect of compassion into the care of the ill, wounded, old or otherwise incapacitated society members. This of course also brought different impacts on patient oriented care focused on the patient, his/her feelings, subjective perception of illness and comfort. The circumstances of the Crimean war and activities of Florence Nightingale and other figures led to the foundation of professional nursing based on fulfilling the need of an individual.

Until 1990 implementation of new nursing methods that were already been accepted in the western countries was practically impossible in Czech Republic. Nursing care was fully dependent on and subjected to the decisions of the doctors. Patient care was fully paternalistic and comprised of complete transfer of responsibility for patient health and direct delegation of all decisions without any regard or respect for the preferences, values or interests of the patient. After 1990 the new models of care started to be slowly introduced into the national health care that were in compliance with the holistic conception where patient has own right and prerequisites must be created for therapeutic relationship based on partnership, which is currently applied to some degree.

The term patient-oriented care as a nursing concept includes the setting of national priorities of the North American health care policy. It shows that the basis of given health care that sees the psychological concept of personality in its self-perception is not only an alternative to care but instead an indispensable part of therapeutic partnership influenced by the humanitarian psychology of C. Rogers that perceives the patient/client as an undivided self-perceptive being. 
The Austrian model is also familiar with the concept of patient-oriented care that offers good background for confrontation of the model of given health care in this country. The problems found are not solely related to the nursing staff that is in close contact with the patient but also to the organisational structure of the health care as a whole including the cooperation from insurance companies, educational institutions, general practitioner system and patient families.

In the Czech Republic the current nursing care should be realised through the method of nursing process that is based on own field concept. Anchored in the Bulletin of the Health ministry of CR no. 9/2004 is the responsibility of every health care giver to work through this method. A method that enables the health care staff to learn to know the patient personally and be thus able to approach him and his treatment on an individual level according to his needs. However, the current situation in practical setting (number of nurses in the wards and the discussion on the way of nurse education) makes it impossible to apply this concept in its full extent which also means that the patient-oriented care is not fully applied even though the staff has been fully prepared and educated for this type of care.

Further education in communication skills and about the new approach methods realised as a part of life-ling education is therefore necessary in order to make patient-oriented care more effective in practice. Possibilities of grants and alternative financing should be used for development of educational curricula thus helping the system of health care to acknowledge the necessity of quality care the public requires and deserves. Practical research not conducted in this study would be necessary form acquiring how the knowledge and skills of patient-oriented care is applied in practice. However, it can be concluded that better agreement need to be reached regarding the evaluation of patient-oriented care in order to ensure it is applied in practice for the benefit of the patient. We perceive the approach of patient-oriented care as a concept that fulfils not only the feelings of human safety and security, but also the ethical basis and high-quality professional care. This research has brought many inspiring concepts for current discussion in situation of insufficiency of qualified general nurses and dispute in nurse education.

\section{References}

[1] Koncepce ošetřovatelství. Věstník MZ ČR č. 2004. In: Ministerstvo zdravotnictví České republiky [online]. (C) 2004-2013 [cit. 2015-11-13]. Dostupné z: http://www.mzcr.cz/Legislativa/dokumenty/vestnik_3648 177811.

[2] HEŘMANOVÁ, JANA. 2012. Etika v ošetřovatelské praxi. Praha: Grada. ISBN 978-80-247-3469-9.

[3] BUŽGOVÁ, RADKA. Etika ve zdravotnictví. 2008. Ostrava: Ostravská univerzita. ISBN 978-80-7368-501-0.

[4] HAŠKOVCOVÁ, Helena, 1998. Manuálek o etice a vstř́ícném chování. Praha: Galén. ISBN 80-85824-87-6.

[5] SALITERER, Iris, Thomas FENZL a Marcel KÖFFEL, 2009. Patientinnen-orientiertekrankenpflege. Klagenfurt: Alpen-Adria University. 230 s. Interní materiál PIK.

[6] Hudon, C., et al. 2011. "Measuring Patients Perceptions of Patient-centered Care: a Systematic Review of Tools for Family Medicine." Annals of Family Medicine 9 (2): 155-64. ISSN 1544-1709.

[7] Epstein, Ronald, M., and Richard, L. S. 2011. "The Values and Value of Patient-centered Care." Annals of Family Medicine 9 (2): 100-3. ISSN 1544-1709.

[8] ROGERS, Carl, R. 1998. Způsob bytí. Praha. Portál. ISBN 80-7178-233-5.

[9] MEARNS, Dave a Brian THORNE, 2013. Terapie zaměřená na člověka: pro využití v praxi. Praha: Grada. ISBN 978-80-247-3881-9.

[10] NYKL.

[11] ŠIFFELOVÁ, Daniela, 2010. Rogerovská psychoterapie pro 21. století. Praha: Grada Publishing. ISBN 978-80-247-2938-1.

[12] BURNARD, Philip. 2001. Effective Communication Skills for HeaLth Professionals. Cheltenham: Nelson Thornes Ltd., ISBN 0748733124.

[13] Epstein, Ronald, M., et al. 2010. "Why the Nation Needs a Policypush on Patient-centered Health Care." Health Affairs 29 (8): 1489-95. ISSN 0278-2715.

[14] ŠVAŘÍČEK, Roman a Klára ŠEĎOVÁ, 2007. Kvalitativní výzkum v pedagogických vědách. Praha: Portál. ISBN 978-80-7367-313-0.

[15] ARCHALOUSOVÁ.

[16] Tomey, A. M., and Alligood, M. R. 2006. "Nursing Theorists and Their Work." St. Louis, Missouri: Mosby 
Elsevier. ISBN 13:978-0-323-03010-6.

[17] http://www.ahna.org/.

[18] KOMÍNKOVÁ, Helena, 2008. Kvalita života. In: MARKOVÁ, Marie, ed. Role sestry specialistky: učební text základního modulu specializačního studia pro sestry a porodní asistentky. 1. vyd. Brno: Národní centrum ošetřovatelství a nelékařských zdravotnických oborů, s. 15-27. ISBN 978-80-7013-484-9.

[19] FARKAŠOVÁ, Dana, et al. 2006. Ošetřovatelství - teorie. Martin: Osveta. ISBN 80-8063-227-8.

[20] KAFKOVÁ, Vlastimila, 1992. Z historie ošetřovatelství. Brno: Institut pro další vzdělávání pracovníků ve zdravotnictví. ISBN 80-7013-123-3.

[21] JAROŠOVÁ, Darja. 2000. Teorie moderního ošetřovatelství. Praha: ISV. ISBN 80-85866-55-2.

[22] JAROŠOVÁ, Darja. 2007. Úvod do komunitního ošetřovatelství. Praha : Grada. ISBN 978-80-247-2150-7.

[23] PLEVOVÁ, Ilona, et al. 2011. Ošetřovatelství I. 1. vyd. Praha: Grada. ISBN 978-80-247-3557-3.

[24] HAŠKOVCOVÁ, Helena, 2002. Lékařská etika. 3. rozšiřr. vyd. Praha: Galén. ISBN 80-7262-132-7.

[25] HOLČÍK, Jan, Pavlína KAŇOVÁ a Lukáš PRUDIL, 2015. Systém péče o zdraví a zdravotnictví. 2 uprav. vyd. Brno: Národní centrum ošetřovatelství a nelékařských zdravotnických oborů. 115 s. ISBN 978-80-7013-575-4.

[26] MOTLOVÁ, Lucie a David HOLUB, 2005. Compliance a adherence: spolupráce při léčbě. Remedia, roč. 15 , č. 6 , s. 514-516. ISSN 0862-8947.

[27] TÓTHOVÁ, Valérie, et al. 2014. Ošetřovatelský proces a jeho realizace. 2. aktualiz. vyd. Praha: Triton. ISBN 978-80-7387-785-9.

[28] KŘÍŽOVÁ, Eva, 1998. Zdravotnické systémy v mezinárodním srovnávání. Praha: [Eva Kř̌̌žová]. ISBN 80-238-0937-7.

[29] ANDRYSEK, Oskar, et al. 2011. Mluv se mnou: kniha o vzájemné komunikaci pacientů, jejich blízkých, lékařů a sester. Praha: Maxdorf. ISBN 978-80-7345-257-5.

[30] VAŇKOVÁ, Miroslava, 2013. Mentorství očima studenta a mentora klinické praxe. Sestra, roč. 23 , č. 3, s. 17. ISSN 1210-0404.

[31] ZÍTKOVÁ, Marie, Andrea POKORNÁ a Erna MIČUDOVÁ, 2015. Vedení nových pracovníků v ošetřovatelské praxi: pro staniční a vrchní sestry. 1.vyd.
Praha: Grada. ISBN 978-80-247-5094-1.

[32] POCHYLÁ, Karla 2005. Koncepce českého ošetřovatelství: základní terminologie: české ošetřovatelství 1. 2. přeprac. vyd. Brno: Institut pro další vzdělávání pracovníků ve zdravotnictví. ISBN 80-7013-420-8.

[33] FRÜHAUFOVÁ, Hana, 2013. Ošetřovatelský proces a jeho význam pro seniora $\mathrm{z}$ pohledu sester $\mathrm{v}$ domovech seniorů [online]. České Budějovice: Jihočeská univerzita $\mathrm{v}$ Českých Budějovicích, Zdravotně sociální fakulta [cit. 2015-08-04]. Bakalářská práce. Vedoucí práce Alena Machová. Dostupné z: http//theses.cz/id/9apliv/Frhaufov-BP finle.pdf.

[34] BÁRTLOVÁ, Sylva, CHLOUBOVÁ, Ivana a TREŠLOVÁ, Marie. 2010. Vztah sestra-lékař. Brno: NOCONZO. ISBN 978-80-7013-536-6.

[35] HOLČÍK, Jan 2010. Systém zdravotní péče o zdraví a zdravotní gramotnost. Brno: Masarykova univerzita ve spolupráci s MSD. ISBN 978-80-210-5239-0.

[36] FILATOVA, Renata, et al. 2014. Paliativní péče třetího tisíciletí. Frýdek-Místek: JOKL. ISBN 978-80-905419-7-9.

[37] RAITER, Tomáš 2010. O kvalitě zdravotní péče rozhodnou pacienti. Medical Tribune CZ: tribuna lékařů a zdravotníků [on-line]. Praha: Medical Tribune CZ, 15.9.2010 [cit. 2015-07-20]. Dostupné Z http://www.tribune.cz/clanek/19128-oecd-o-kvalitě-zdrav otní-pece-rozhodnou-pacienti.

[38] PROCHÁZKOVÁ, E. 2014. Práce s biografií a plány péče. Praha: Mladá fronta. ISBN 978-80-204-3186-8.

[39] VOJTOVÁ, HANA 2014. Smyslová aktivizace v české praxi. Prachatice: Institut vzdělávání. ISBN 978-80-260-5804-5.

[40] FRIEDLOVÁ, Karolína 2007. Bazální stimulace v základní ošetřovatelské péči. Praha: Grada. ISBN 978-80-247-1314-4.

[41] NEDĚLKOVÁ, Hana a Renata HALMO, 2007. Kinestetická mobilizace: skriptum pro účastníky kurzu Kinestetická mobilizace. Most: Nemocnice Most. ISBN 978-80-239-9260-1.

[42] FEIL, Naomi. 2000. Validation ein Weg zum Verständnis verwirrter alter Menschen. 5. überarbeitete Aufl. München: E. Reinhardt. ISBN 3-497-01513-X. 